\title{
The board of directors and international decision-making
}

\author{
Leticia Pérez-Calero Sánchez" \\ University of Pablo de Olavide (Seville) \\ $\mathrm{M}^{\mathrm{a}}$ del Mar Villegas Periñán and Carmen Barroso Castro \\ University of Seville
}

\begin{abstract}
This paper develops a view of how specific elements of the directors' human and social capital can enhance a company's international performance. We have taken the view that the board is an active participant in the firm's management, and we have therefore set out and tested a number of arguments related to the board's role in the adoption of international decisions. Specifically, our results point to the need to incorporate board members with high levels of education and international background with ability to learn and process information and to help international decision-making. As shown by our results, a high level of external connectivity of directors could have negative repercussions for internationalization since they limit the time spent on the board and therefore reduces the cohesion and trust inside the board. The implications of this research, therefore, are important for both executives and academics, as it helps to know what attributes contribute to the board's effectiveness in such a way as to positively affect the internationalization of the firm.
\end{abstract}

Keywords: Board of directors, human capital, social capital, firm’s internationalization.

JEL codes: C33, M16.

* Corresponding author. Email: $\underline{\text { lcalero@upo.es }}$

ISSN 0212-1867 / e-ISSN 1989-3558

(C) ESIC Editorial, ESIC Business \& Marketing School

DOI: $10.7200 /$ esicm.146.0443.2i

http://www.esic.edu/esicmarket 


\section{Introduction}

The literature on corporate governance highlights the importance of the board's effectiveness for achieving company success (Petrovic, 2008; Nicholson and Kiel, 2004). Boards of directors are a key element in the study of corporate governance, not only because of their disciplinary or controlling roles, but also because of their active participation in their company's key decisions (Barroso, De la Concha, Vecino and Villegas, 2009). We believe that the board's participation in a company's major international decisions is particularly important. Globalisation and the liberalisation of financial markets have dramatically changed the business environment, making internationalisation strategies more important than ever before. Businesses around the world are becoming increasingly globalised, which encourages firms to develop an international presence. Under these conditions, firms need to have effective boards that can make appropriate decisions on internationalisation.

However, despite the importance of the board for the organisation's results and the high degree of internationalisation that many firms have experienced in recent years, the majority of studies relating to these two concepts continue to rely on traditional variables as the explanatory elements for their models: the proportion of external directors; board size; or duality of CEO / President of the Board of Directors (Ellstrand, Tihanyi and Johnson, 2002; Datta, Musteen and Herrmann, 2009; Petrovic, Kakabadse, A. and Kakabadse, N.K., 2006; Kim, Prescott and Kim, 2005; Rivas, 2012; Lien, Piesse, Strange and Filatotchev, 2005). In general, these variables have been characterised by ambiguity, and investigators have been unable to reach a consensus on the variables that define the boards that are more or less effective in fulfilling their roles, and therefore, in affecting the firm's international performance (Kim, 2005; Kim and Cannella, 2008; Daily and Dalton, 1993; Dalton, Daily, Johnson and Ellstrand, 1999).

Furthermore, from our point of view, these works have proposed a set of unsuitable and incomplete models, in which boards of directors are treated as homogenous groups, without taking account of their social and human dimensions (Tian, Haleblian and Rajagopalan, 2011; Hillman and Dalziel, 2003). More in-depth studies need to be carried out into how board composition, through its human and social capital, affects the firm's international performance. While human capital allows directors to become familiar with and understand the logic and dynamics of external markets and the global business environment, its social capital provides external information that mitigates the risks associated with internationalisation strategies.

Hillman and Dalziel (2003) propose a theoretical model that examines how board capital, consisting of human and social capital, affects the firm's performance. In the wake of this study, many researchers have carried out empirical analyses of how certain elements of the board's human and social capital can be used to improve the firm's principal organisational results (Lester, Hillman, Zardkoohi and Cannella, 2008; Stevenson and Radin, 2009; Kor and Sundaramurthy, 2009; Wincent, Anokhin and Boter, 2009; Tian et al., 2011; Haynes and Hillman, 2010; Dalziel, 
Gentry and Bowerman, 2011). However, the joint effect of these two elements on the firm's international results has been overlooked. While there are a few prior studies that analyse the effect of the human capital of the TMT on the firm's principal international results, (Athanassiou and Nigh, 2002; Peyrefitte, Fadil and Thomas, 2002; Reuber and Fischer, 1997; Sambharya, 1996), there are virtually no studies that analyse the board's human capital, and even fewer that also include external social capital. Therefore, the principal objective of this study is to carry out an empirical analysis of the importance of the board of directors on the principal international results, including a study not only of the resources brought by the board through its own human capital, but also through its access to new, external resources.

In this study we aim to highlight the importance for the firm of the board's capacity, through its knowledge and abilities, to tackle the complexity and the high demand for information-processing associated with international diversification. The knowledge that the firm's board members contribute, through their experience, could be used in international markets to overcome the risks associated with foreign operations (Ellstrand et al., 2002). Similarly, although individual board members possess unique resources, they also require access to complementary resources, such as information, power and influence, so that they can be involved in the management of international business. A diversity of external contacts gives board members greater access to information on the markets, innovations, capital, investors and other key assets that are needed to launch a new business. These connections could also benefit the company by serving as a communication channel between external organisations and the firm, and would be a very important tool when particular information is required to mitigate the risks associated with internationalisation.

This work is structured as follows: in the first section we set out the reasons for choosing this topic, and explain our main objectives. In the following sections we carry out a literature review, which will help us to formulate a set of hypotheses. In the final section we present the empirical evidence and an analysis and interpretation of the data obtained.

\section{Literature review and working hypotheses}

\section{The human capital of the board}

The human capital of the board can be defined as the capabilities and knowledge that individual members bring to the board, stemming from their investment in education and/or experience (Stevenson and Radin, 2009; Becker, Huselid and Ulrich, 2001; Nicholson and Kiel, 2004; Wincent, Anokhin and Örtqvist, 2010; Kor and Sundaramurthy, 2009; Lester et al., 2008; Becker, Chambers and Wilks, 1988; Coleman, 1988). While knowledge acquired through experience (accumulated or not) leads to the adoption of specific human capital, learning, through education, tends to have a more general connotation, since it is assumed that the benefits of educa- 
tion encompass not only learned information, but also the abilities associated with learning through a diversity of situations. Both elements are included in this study.

The structures for learning and knowledge gained from a higher level of formal education will be of immense value for boards (Wincent et al., 2010; Reeb and Zhao, 2009; Kim and Lin, 2010). Board members with high levels of education bring a greater ability for learning and more effective information-processing (Bantel and Jackson, 1989; Hambrick and Mason, 1984; Pennings, Lee and van Witteloostujin, 1998; Wiersema and Bantel, 1992) and they are therefore able to become involved in the company's strategies. Board members with high levels of education are more likely to participate in the firm's international strategies, since these require the directors to quickly assimilate large amounts of complex information and if the knowledge structures are in place, they are more able to interpret and categorise the information presented to them. There is evidence of a positive relationship between higher levels of education among directors and their willingness to make use of external information and external consultants or to monitor more extensively the firm's accounting systems (Crabtree and Gomolka, 1991).

More highly educated people are better able to find creative solutions to help the firm they represent (Wincent et al., 2009). They are fundamental to the acquisition, use and understanding of knowledge, and the development of abilities that support effective decision-making in an international context. A higher level of education is also associated with openness to innovation and a tolerance of ambiguity (Goll, Johnson and Rasheed, 2007); two fundamentally important aspects when the board is considering strategic change linked to the firm's internationalisation.

We therefore propose the following working hypothesis:

\section{H1. The board members' level of education is positively related to the degree of the firm's international diversification.}

In addition to examining the board's level of education, the majority of studies focus on a more specific human capital, derived from the directors' experiences (Stevenson and Radin; 2010; Tian et al., 2011; Kroll, Walters and Wright, 2008; Haynes and Hillman 2010; Kor and Misangyi, 2008; Sirmon, Arregle, Hitt and Webb, 2008). Experience (either personal or via feedback from an event) improves future behaviours specifically because of the knowledge that has been acquired. Individuals who learn and accumulate knowledge through experience feel more enabled and make a more active contribution to the firm's competitive advantage (March, 1999). Directors with experience can participate more fully in their role because, through their learning, they might be able to make a positive contribution to the firm's results. The possession of relevant knowledge and learning through experience, therefore, could be important for explaining board effectiveness (Kroll et al., 2008).

Board members' international experience brings a specific tacit knowledge, which is one of the resources that is hardest to imitate (Barney, 1991). Firms can improve 
their ability to face the challenges of the international environment by electing members to the board that have the particular characteristics, abilities or experience required for the internationalisation process. A director's international experience might be an attractive characteristic for other firms that are interested in acquiring this tacit knowledge.

Many studies have researched the role of the top management team in the firm's international behaviour (Athanassiou and Nigh, 2002; Peyrefitte et al. 2002; Reuber and Fischer, 1997; Sambharya, 1996), and have established links between the TMT's international experience and internationalisation, but few studies have examined the effect of the board of director's influence on the firm's internationalisation. Board members with experience of international markets possess the knowledge and abilities to deal with the actual institutions, firms and networks in foreign markets. They also help with the collection, analysis and interpretation of information on worldwide opportunities. They can therefore play a fundamental supporting role in the decision-making process with regard to international business (Zahra, Priem and Rasheed, 2007).

Finally, it is important to point out that, beyond their general educational level, board members with a foreign education will be more open-minded towards other cultures. Board members who have studied abroad will be more aware of international problems and will be more inclined to look for international opportunities. We therefore believe that the international background of the board members, measured by their international experience and/or education, is positively related to the level of international development achieved by the firms that they govern.

Therefore:

\section{H2. The board members' international background is positively related to the degree of the firm's international diversification.}

\section{Social capital of the board}

As we have suggested in the hypotheses above, the members of the board are resources for the firm and will be evaluated according to their competences and knowledge (Barney, 1991; Grant, 1991; Hillman, Cannella and Paetzold, 2000). Similarly, researchers consider that boards are useful for giving access to resources via their social connections. The firm will try to develop strategies that make use of the strengths of the resources that it possesses, but will also attempt to acquire new, external resources. If we consider that the board brings exogenous resources and capabilities to the firm, which enable continuous adaptation to the competitive environment, and that social capital provides access to those exogenous resources, which are mobilised through relationships, then this means that external social capital plays a critical role in the survival and success of a firm at international level. Firms today adopt strategies that are oriented to international business, and therefore members 
of the board of directors must be given privileged access to the network of external actors so that they can help to establish these strategies (Yeung, 2002). In practice, this means that the board can be used as a link to other firms and governing bodies, to help it to establish operations and strategic alliances abroad (Pfeffer and Salancik, 1978).

As with the general management team, board members who are directors on other boards can convert their experience, through their interlocks, into an important resource that allows them to further develop their roles, by applying their external experiences to the firm. Some studies have examined the transmission of ideas through the board's social ties, establishing a positive relationship between interlocks and the firm's adoption of new strategies (Geletkanycz and Hambrick, 1997; Mizruchi, 1996; Westphal et al., 2001). Thus, while strategic decisions relating to investment in $\mathrm{R} \& \mathrm{D}$, entry into new markets or setting up subsidiaries in international markets bring significant benefits for the firm's growth, they also tend to be complex operations, given the high levels of uncertainty and risk of failure linked to them (Sanders and Carpenter, 1998). In this context, interlocks are a very important tool that gives board members the opportunity to access information that mitigates risks and to seek information from other firms. This type of link could benefit the firm by acting as a communication channel between external organisations and the firm. Connelly et al. (2011) studied the effects of interlocks on the probability of a firm adopting an international strategy and point out that the interlocks of a firm that has successfully put into practice an international strategy have a positive effect on the likelihood that other firms will adopt the same strategy.

It is therefore necessary for a firm to have strong social networks, created by the members of its board, in order to gain information and experience of foreign markets. Moreover, the information acquired is particularly influential, because it comes from a trustworthy source (Geletkanycz and Hambrick, 1997).

However, despite these benefits, there can be some costs. A director who belongs to multiple boards has limited time and attention to dedicate to any particular board (Carter and Lorsch, 2004; Conger, Lawler and Finegold, 2001). Holding a directorship is seen as a prestigious post that brings very valuable learning opportunities, and therefore board members might be tempted to accept invitations to serve on several boards at the same time (Useem, 1982). It is likely that these board members would be unprepared for board meetings through lack of time, or might be unable to attend meetings on a regular basis, in which case their contribution to the board would be negatively affected (Finkelstein and Mooney, 2003; Conger et al., 2001; Kor and Sundaramurthy, 2009). We should not forget that internationalisation is a complex and costly decision and requires the full participation, support and collaboration of the entire board of directors, and therefore the reduced participation or commitment of members who belong to multiple boards is very likely to have a negative effect.

We therefore propose the following working hypothesis: 
H3: There is a curvilinear (inverted-U) relationship between the degree of the external connections of directors who are members of multiple boards and the degree of the firm's international diversification.

\section{Methodology}

\section{Sample and data collection}

The sample of firms used in this study consists of the Spanish firms registered on the Madrid Stock Exchange and which were quoted on the Continuous Market during the period 2005-2010. These firms were chosen because of their requirement to publish data pertaining to their corporate governance and international performance. We then eliminated those firms that are classed as financial service companies (if they include estate agency services), because of the difficulty of interpreting all of the data related to this sector; companies that were removed from the stock market during the analysis period (we only included firms that were quoted on the stock market from 2005-2010 inclusive); and firms whose annual reports we did not have access to. This left a group of 84 firms, but from this total we had to remove firms with no international activity in one or more years of the study period 2005-2010. We understand no international activity to mean that the entirety of the firm's sales and assets are attributable to the domestic market; and we therefore included firms in the sample with international assets but no sales, and vice versa.

After applying these restrictions, the sample comprised 78 firms and 468 observations for each of the variables used in our study.

\section{Dependent variable}

International diversification is a strategy a firm uses to sell its products or services in new geographical markets that extend beyond national and regional boundaries (Hitt, Tihanyi, Miller and Connelly, 2006). Internationalisation has been measured in different ways in the literature and continues to be the subject of debate (Elango and Sethi, 2007; Reuber and Fischer, 1997). Sullivan (1994) argues that multi-item measures should be used, rather than individual variables. This author was one of the first to identify the term "degree of internationalisation of a firm", defined by three dimensions: the performance aspect (foreign sales); the structural aspect (foreign assets); and attitudinal aspects (the international experience of top management). Ramaswamy, Kroeck and Renforth (1996) also recognise that multi-item measures are more reliable than single-item measures, and identify various limitations of using a single measure.

In this study, and in line with Sullivan (1994) and other studies (Daily, Certo, and Dalton, 2000; Lee and Park, 2006; Rivas, Hamori and Mayo, 2009; Sanders 
and Carpenter, 1998), we measure a firm's internationalisation by more than a single dimension; namely, through its performance and its structure. These dimensions both represent the "depth" of the firm's foreign participation (Thomas and Eden, 2004). Like Reuber and Fischer (1997), we have not used experience as a component of internationalisation, as experience is already one of the concepts in our hypotheses.

The performance dimension is usually calculated by using the ratio of sales in foreign subsidiaries to total sales (FSTS) (Geringer, Beamish and daCosta, 1989). This captures the importance of international operations as part of the firm's overall operations and therefore the degree of its dependence on foreign markets (Thomas and Eden, 2004). The structural dimension is usually calculated as the percentage of foreign assets to total assets (FATA) (Daniels and Bracker, 1989). FATA reflects a firm's confidence regarding the number of foreign assets it owns. In the international business literature, the dimensions of international sales and assets are related to the firm's dependence on foreign consumer markets and foreign resources (Sanders and Carpenter, 1998). Likewise, and using the data collected from the database described above, we calculated the total number of each firm's assets in external regions or markets and divided that figure by the total number of assets owned by the firm.

The theoretical range for each dimension is 0 to 1 . The two variables (foreign sales and foreign assets) will form our composite measure of the degree of internationalisation and therefore we will use a theoretical range from 0 to 2 . To summarise, we chose this composite measure because it is a better measurement of the firm's internationalisation than unidimensional variables (Lu and Beamish, 2004).

The information was extracted from the audited reports obtained from the CNMV database. These consolidated reports (the majority issued by PricewaterhouseCoopers, Ernst \& Young and Deloitte) provide information relating to the distribution of sales and assets for each of the geographical sectors in which the firm operates and owns its assets. From this data we can obtain information on the sales and assets of the firm both in Spain and in other regions or markets.

\section{Independent variables}

On one hand we have the variables that define the board's human capital, such as educational level and international background, and on the other hand, we have the variables that define social capital, such as the interlocks between boards.

In order to calculate the board members' level of education, we have codified the education variable as 1 if the board member holds a Masters Degree and 0 if they do not (Ruigrok, Peck and Tacheva, 2007; Westphal and Zajac, 1995; Wiersema and Bantel, 1992). Almost all of the board members included in our sample have a qualification in higher education (in law, economics, engineering, etc.) and a high percentage of them have also attained a Masters Degree. In Spain, until the new regulation regarding the European Credit Transfer System, having a degree was a 
prerequisite for taking a Masters. To measure board members' international background (experience and/or training abroad), we used a dichotomous variable that was codified as 1 if the board member occupies or has occupied a post abroad for any time or, if they were working abroad, if they were placed in an international division. Similarly, we also consider that they have an international background if they have attained a higher education qualification abroad. We codified this variable as 0 if this had not occurred (Rindova, 1999). The board's educational level and its international background were measured as the percentage of board members holding these resources over the total number of board members (Wincent et al., 2009)

We define the board's external social capital through its interlocks; the links formed when one board member sits on the board of another firm. Measuring interlocks has been used previously in the literature on boards of directors (Kor and Sundaramurthy, 2009; Wincent et al., 2009; Haney and Hillman, 2010; Tian et al., 2011; Filatotchev, 2006; Pombo and Gutiérrez, 2011; Ortiz, Aragón, Delgado and Ferrón, 2012). To calculate the figure we added the total number of links from all board members and divided it by board size -the total number of board members. The resulting measure is the average number of interlocks per board.

To obtain the information on each member's interlocks, we turned to Axesor, a consultancy firm specialising in providing information on firms and their executives, derived from official records. The information provided by Axesor is available from the Boletín Oficial del Registro Mercantil (the Official Mercantile Registry Newsletter) and includes a list of directorships that each board member holds on one or more boards -both listed and unlisted on the stock exchange.

\section{Control variables}

In accordance with prior studies on corporate governance, we have included the following control variables that might affect the proposed relationships: firm size; business sector; firm age; board size; duality (of President and Chief Executive); and the proportion of external board members.

Board size is commonly used as a control variable, given its relationship with the firm's results. Bigger firms are more actively involved in exporting and undertaking international operations (Calof, 1993; Zahra et al., 2007), probably because they have greater resources. Bigger firms also benefit from more specialised staff, who are capable of exploring foreign markets and are better able to supervise international expansion. Firm size has been measured, as in prior investigations, by the logarithm of the number of employees in each firm during the period of our study.

The firms included in our sample cover a broad mix of sectors, since operating in a particular sector might affect internationalisation (Rivas et al., 2009). We have therefore included the sector as a control variable in our study. We have used the information from the stock market sectoral classification database proposed by the CNMV (National Share Market Commission), codified as follows: 1) petroleum and 
energy; 2) raw materials, industry and construction; 3) consumer goods; 4) consumer services; 5) financial and real estate services; and 6) technology and communications. Taking into account the differences in the frequency of observations in each sector, we have assigned a " 1 " to sectors $1,4,5$ and 6 ; " 2 " to sector 2 ; and " 3 " to sector 3 .

The third variable we have used is firm age. This variable is measured as the number of years that the firm has been in existence. To calculate this, we deducted the year of the firm's founding from the year of our study. We have included this variable because older firms have greater opportunities for internationalising their operations and developing the experience required to exploit these operations and increase their returns (Calof, 1998; Zahra et al., 2007; Barroso, Villegas and PérezCalero, 2011).

Board size, measured as the number of members of the board, is an important demographic characteristic which could affect the firm's results (Kim, 2005, 2007). There are a greater number of abilities and specialised opinions within a large board than in a smaller board and the former is better equipped to establish external links. They are therefore more likely to have access to critical resources (Goodstein, Gautam and Boeker, 1994), which will affect the firm's general performance (Amason and Sapienza, 1997). As for influencing internationalisation, it has been argued that firms with larger boards are more internationalised because of the demand for more information from the board of directors, and the ability of a group to process information depends on the number of people in that group (Sanders and Carpenter, 1998). We have measured board size by the number of members of the board.

Boards of directors may be structured in such a way that the CEO also acts as President of the Board (duality), or where the post of CEO and President are separated. This can influence the firm's internationalisation and must therefore be controlled in our study. Thus, for example, some authors propose that internationalisation requires that there should be separate posts for President and Chief Executive (no duality), since in complex environments firms require a greater delegation of authority and the division of responsibilities, which allows for a greater breadth of experience (Holm and Schuler, 2010). Non-duality will increase the capacity for information-processing and overseeing the management and will bring different networks and additional resources into play (Singla, George and Eliyaht, 2010). Conversely, when the CEO is also President of the Board, he or she tends to support initiatives that produce more secure results in order to protect their position on the board, and, therefore, will avoid risky strategies such as internationalisation (Ellstrand et al., 2002). For this measure we created a dichotomous variable with the value 1 when there is duality and 0 when there is none.

Finally, we controlled the proportion of external (non-executive) directors on the board, which indicates the relative impact that this type of director has on the board's decisions (Kor and Sundaramurthy, 2009; Ruigrok et al., 2006). A high percentage of external board members could have a positive effect on internationalisation, as it would help to control the management team's actions and would provide the resources required for international expansion (Singla et al., 2010; Datta, Mus- 
teen and Herrmann, 2009). Conversely, internal board members demonstrate an adverse behaviour to risk and avoid high levels of international commitment (Filatotchev, Dynomina, Wright and Buck, 2001). To calculate this variable we categorised the type of board member. Following the indicators of the codes of good corporate governance, we classified the board members into four main categories: 1) internal or executive board members, who are part of the management team or hold a position within the firm; 2) external representative directors, that is, those elected to represent shareholders with a significant shareholder participation; 3) external independent boards members -high profile professionals who can carry out their function on the board without being affected by their relations with the firm, its major shareholders or its management; and 4) other external board members who, because of special circumstances or links cannot be considered as being either representative or independent (CNMV, 2006). We calculated the total number of external board members on each board as the sum of the directors classified as 2, 3 and 4, divided by the total number of board members.

The information for the control variables was taken from several sources, depending on whether the variable related to the firm or the board. At the firm level, we used the Osiris database and the stock exchange sectoral classification published by the CNMV. The Osiris database contains financial and accounting information on firms, banks and insurance companies from all over the world, and which are listed on the stock exchange. Authors such as Jackling and Johl (2009) and Singh and Gaur (2009) have used this database in their studies of corporate governance. From this source we obtained information on the size and age of the firm: the number of employees and the date of the firm's foundation. The sectoral classification provided information on the sector within which each firm operates. The information on the boards was taken from the corporate governance reports available from the CNMV. These reports provided information on the number of members on each board, whether there is duality of President and Chief Executive and the type of directors that make up the board, using the following categories: executive, representative, independent, and other external.

\section{Results}

Table 1 is a summary of the descriptive statistics (the number of observations, minimum, maximum and average values and standard deviation) of the continuous variables used in our model, and the percentage frequencies of the dichotomous variables. The descriptive statistics of the sample show that the degree of internationalisation of the firms in the study is fairly moderate $(0.7)$. With regard to the board's human capital, 39\% have an international background and $45 \%$ hold a Masters Degree. Finally, the average number of interlocks for the firms in our sample was 4.19 , with a maximum value of 12 interlocks per firm, which is considerably higher than the average for the group. 
Table 1. Descriptive Statistics

\begin{tabular}{|c|c|c|c|c|c|c|}
\hline Variable & $\begin{array}{l}\text { Number of } \\
\text { observations }\end{array}$ & Mean & S.D & $\begin{array}{l}\text { Minimum } \\
\text { values }\end{array}$ & $\begin{array}{l}\text { Maximum } \\
\text { values }\end{array}$ & Frecuency \\
\hline \multicolumn{7}{|l|}{ Variables continuas } \\
\hline edu & 468 & 0,45 & 0,2 & 0 & 1 & \\
\hline interback & 468 & 0,39 & 0,22 & 0 & 1 & \\
\hline interl & 468 & 4,19 & 2,03 & 0,33 & 11,8 & \\
\hline firmsize & 468 & $13.155,9$ & $33.587,76$ & 6 & 285.106 & \\
\hline age & 468 & 50,91 & 34,25 & 2 & 164 & \\
\hline boardsize & 468 & 10,9 & 3,43 & 5 & 21 & \\
\hline non-executive directors & 468 & 0,81 & 0,12 & 0,33 & 1 & \\
\hline \multicolumn{7}{|l|}{$\begin{array}{l}\text { Variables categóricas } \\
\text { y dicotómicas }\end{array}$} \\
\hline sector 1 & 156 & & & & & 33,33 \\
\hline sector 2 & 156 & & & & & 33,33 \\
\hline sector 3 & 156 & & & & & 33,33 \\
\hline no- duality & 145 & & & & & 30,98 \\
\hline duality & 323 & & & & & 69,02 \\
\hline
\end{tabular}

Table 2 shows the correlation matrix of the variables used. All of the VIFs are substantially lower than 2 , and there are therefore no problems of multicolinearity in our model.

Table 2. Zero-order Correlation

\begin{tabular}{|c|c|c|c|c|c|c|c|c|c|c|c|}
\hline & divint & edu & interback & interl & firmsize & age & sector & boardsize & duality & $\begin{array}{c}\text { non- } \\
\text { executive } \\
\text { directors }\end{array}$ & VIF \\
\hline intdiv & 1 & & & & & & & & & & \\
\hline edu & $0,3^{* *}$ & 1 & & & & & & & & & 1,25 \\
\hline interback & $0,21 * *$ & $0,39^{* * *}$ & 1 & & & & & & & & 1,26 \\
\hline interl & $-0,08^{\dagger}$ & 0,06 & $0,13 * *$ & 1 & & & & & & & 1,10 \\
\hline firmsize & $0,12^{*}$ & $-0,01$ & 0,03 & $-0,05$ & 1 & & & & & & 1,17 \\
\hline age & -0.03 & 0,06 & $0,13^{* *}$ & $-0,04$ & $-0,04$ & 1 & & & & & 1,09 \\
\hline sector & 0,07 & $0,15^{* *}$ & $-0,04$ & $-0,14^{* * *}$ & $-0,25^{* * *}$ & $0,19 * *$ & 1 & & & & 1,25 \\
\hline boardsize & $0,1^{*}$ & $-0,13^{* * *}$ & $-0,15^{* * *}$ & $-0,06$ & $0,27^{* * *}$ & $-0,06$ & $-0,3^{* *}$ & 1 & & & 1,36 \\
\hline duality & 0,00 & 0,03 & 0,04 & $-0,07$ & $0,13^{* *}$ & $-0,08^{\dagger}$ & $-0,05$ & $0,09^{\dagger}$ & 1 & & 1,10 \\
\hline $\begin{array}{c}\text { non- } \\
\text { executive } \\
\text { directors }\end{array}$ & 0,02 & $0,1^{*}$ & $-0,03$ & $-0,04$ & $-0,1^{*}$ & $0,13^{* *}$ & $-0,04$ & $0,27^{* *}$ & $-0.18^{* * *}$ & 1 & 1,27 \\
\hline
\end{tabular}

We now go on to estimate our theoretical model using linear regression. One of the approaches to analyzing data from several firms at different points in time is through an MCO regression. This is known as pooled regression (pooled OLS).

We use OLS to examine our hypotheses as this technique enables non-linear statistical association to be analysed: non-linear components were represented by the square of the variables. Prior studies that propose the existence of a relationship 
between external links and performance have also used OLS regressions (Carpenter and Westpthal, 2001; Filatotchev, 2006; Tian et al., 2011).

Our model uses dichotomous variables or temporal dummies for each year of the sample, to allow us to capture unobservable events that are common to all firms during a particular period. These dichotomous variables can be used to control the events experienced by all of the firms in a given year, which reduces important biases.

As has been suggested in other studies (Wincent et al., 2009; Kor and Sundaramurthy, 2009), and in order to make our results more robust with regard to the choice of variables, we also considered other ways of measuring our dependent variable -internationalisation. While this work defends the use of a composite measure to calculate the degree of internationalisation of a firm, we consider the use of international sales in isolation (Autio, Sapienza and Almedida, 2000; Jaw and Lin, 2009; Qian, 2002; Tallman and Li, 1996; Wolff and Pett, 2000; Chen, 2011). By substituting these variables in each of the proposed models, our results lose significance. The $\mathrm{R}^{2}$ is considerably reduced in each of the models, which would indicate that the significance of the predictive capability of the model is reduced. The joint significance test of our explanatory variables also decreases. All of this backs up our choice of dependent variable.

Table 3. Results of Pooled OLS Regression Models

\begin{tabular}{|c|c|c|c|c|c|c|c|c|c|c|}
\hline & \multicolumn{2}{|c|}{ Model 1} & \multicolumn{2}{|c|}{ Model 2} & \multicolumn{2}{|c|}{ Model 3} & \multicolumn{2}{|c|}{ Model 4} & \multicolumn{2}{|c|}{ Model 5} \\
\hline & $\beta$ & $\mathrm{t}$ & $\beta$ & $\mathrm{t}$ & $\beta$ & $\mathrm{t}$ & $\beta$ & $\mathbf{t}$ & $\beta$ & $\mathrm{t}$ \\
\hline firmsize & $1.73^{* *}$ & 3,01 & $1,49 *$ & 2,87 & $1,39 *$ & 2,88 & $1,28^{* *}$ & 2,81 & $1,30 * *$ & 2,81 \\
\hline age & $-0,00$ & $-1,10$ & $-0,00$ & $-1,24$ & $-0,00$ & $-1,62$ & $-0,00^{+}$ & $-1,72$ & $-0,00$ & $-1,60$ \\
\hline sector & $0,08 * *$ & 2,73 & $0,06^{*}$ & 2,12 & $0,07^{*}$ & 2,58 & $0,06^{*}$ & $-1,59$ & $0,06^{*}$ & 2,12 \\
\hline boardsize & $0,01 *$ & 2,18 & $0,02 * *$ & 3,47 & $0,03 * *$ & 4,00 & $0,02 * * *$ & 3,82 & $0,02 * * *$ & 3,67 \\
\hline dualidad & $-0,03$ & $-0,66$ & $-0,05$ & $-1,28$ & $-0,06$ & $-1,38$ & $-0,07$ & $-1,59$ & $-0,07$ & $-1,61$ \\
\hline $\begin{array}{l}\text { No- } \\
\text { executive } \\
\text { directors }\end{array}$ & 0,02 & 0,08 & $-0,21$ & $-1,06$ & $-0,22$ & $-1,10$ & $-0,2$ & $-1,03$ & $-0,23$ & $-1,14$ \\
\hline edu & & & $0,75^{* * *}$ & 7,11 & $0,63 * *$ & 5,87 & $0,64 * * *$ & 5,96 & $0,65^{* * *}$ & 6,12 \\
\hline interback & & & & & $0,3 * *$ & 2,99 & $0,32 * *$ & 3,24 & $0,32 * * *$ & 3,24 \\
\hline interl & & & & & & & $-0,03$ ** & $-2,65$ & $-0,02^{+}$ & $-1,74$ \\
\hline interl $^{2}$ & & & & & & & & & $-0,00$ & $-0,94$ \\
\hline anual effect & \multicolumn{2}{|c|}{ si } & \multicolumn{2}{|c|}{ si } & \multicolumn{2}{|c|}{ si } & \multicolumn{2}{|c|}{ si } & \multicolumn{2}{|c|}{ si } \\
\hline $\mathrm{F}$ & \multicolumn{2}{|c|}{$2,49^{* *}$} & \multicolumn{2}{|c|}{$8,41 * * *$} & \multicolumn{2}{|c|}{$8,90 * *$} & \multicolumn{2}{|c|}{$8,91 * *$} & \multicolumn{2}{|c|}{$8,30 \approx *$} \\
\hline $\mathrm{R}^{2}$ & \multicolumn{2}{|c|}{0,054} & \multicolumn{2}{|c|}{0,15} & \multicolumn{2}{|c|}{0,169} & \multicolumn{2}{|c|}{0,181} & \multicolumn{2}{|c|}{0,183} \\
\hline S.E. & \multicolumn{2}{|c|}{0,459} & \multicolumn{2}{|c|}{0,446} & \multicolumn{2}{|c|}{0,432} & \multicolumn{2}{|c|}{0,429} & \multicolumn{2}{|c|}{0,429} \\
\hline $\begin{array}{l}\text { number of } \\
\text { observations }\end{array}$ & \multicolumn{2}{|c|}{468} & \multicolumn{2}{|c|}{468} & \multicolumn{2}{|c|}{468} & \multicolumn{2}{|c|}{468} & \multicolumn{2}{|c|}{468} \\
\hline
\end{tabular}

To analyse the linear regression we used the Stata/SE 10.0. program.

Following our pooled regression analysis, we propose various models, to include each of the working hypotheses. In model one of Table 3 we introduce the control variables, three of which are significant: board size, firm size, and sector. Despite the 
lack of significance in the other control variables, these are, in theory, relevant and should remain in the model. All of these variables, as mentioned above, have been positively linked to the firm's international diversification. Models 2 to 5 are designed to test the proposed hypotheses. We have taken into account the problems of heteroscedasticity, and where this has been detected, we have estimated a robust model.

Hypotheses 1 and 2 propose that both the educational level of the board members and their international background are positively related to the degree of international diversification of the firm. According to models 2 and 3, analysis confirms both of the hypotheses put forward $(b=0.75 p<0.001$ and $b=0.3 p<0.01$, respectively).

In model 4 , however, the estimated coefficient of the external links is significant but with a negative value $(b=-0.03 p<0.01)$. To test the curvilinear relationship, we added the squared value to the regression equation in model 5 . As shown in the table, the square of the external links was negative and non-significant; the coefficient of the first order effects was now negative, but with less significance than in the previous model. We cannot therefore accept our hypothesis 3 .

Finally, we would point out that while model 1 explains $5.4 \%$ of the variance, this percentage increases through the models, rising to slightly above $18 \%$ in model 5. Bearing in mind that this percentage is very similar to that of model 4 , this would indicate that if we add the squared effects of the external links variable, our model gains no significance at all, as we should have considered a linear effect between the two variables. We will examine this aspect in greater detail in the next section. The significance test of our explanatory variables also shows how the variables were significantly different to 0 in all of the models ( $\mathrm{p}<0.001$ for models $2,3,4$ and 5 ).

\section{Discussion and conclusions}

Much of the previous research into boards of directors has studied the influence of this governing body on the firm's results, without considering the human and social capital of its members. Our work looks at the importance of electing board members with particular abilities, knowledge and relationships that enable the firm to achieve good international results. Given that foreign expansion and the development of international operations lead to increased environmental complexity and uncertainty and, therefore, to greater potential risks for the firm, it is vital to elect directors who are able to identify and exploit opportunities in international territories.

Our results confirm the relationship between the educational level and the degree of international diversification. Specifically, we can claim that holding an additional Master Degree or specialist qualification can increase the ability of the board to influence the degree of a firm's international diversification. Sanders and Carpenter (1998) argue that internationalisation demands a greater level of information from the board members, and that the ability of the group to process this information depends on its competences and abilities (Carpenter and Fredrickson, 2001). Other 
authors (Wincent et al., 2009; Reeb and Zhao, 2009; Kim and Lin, 2010) claim that education is directly related to the ability to learn and process information, which enables the board members to be more efficient in collecting, filtering and processing the great diversity of information in the complex international environment. As has been demonstrated for the TMT (Hambrick and Mason, 1984; Bantel and Jackson, 1989; Wiersema and Bantel, 1992; Datta and Rajagopalan, 1998; Karami, Analoui and Kakabadse, 2006), some highly qualified board members make more rational contributions to the decision-making process, reaching more creative solutions to complex problems. Similarly, they bring a greater confidence to the decisionmaking process, increasing the number of points of view and encouraging others to be more accepting of change. All of this helps to increase the ability of the board to promote high-risk strategies (Amason, Shrader and Tompson, 2006), such as internationalisation.

Our analysis also confirms the influence of an international background on international diversification. This result supports the idea proposed by some authors (Henderson, 2005; Barroso et al., 2011; Rivas et al., 2009; Rivas, 2012) that the international background of the board members reduces environmental uncertainty and dependence, so that the board members are more confident when making decisions on internationalisation. Likewise, studying a course at international level increases the specialised knowledge required for operating in international markets, all of which aids the collection, analysis and interpretation of information regarding global opportunities, and enables the board to play a fundamental role in the decision-making process at international level (Zahra et al., 2007; Hambrick, Geletkanycz and Fredrickson, 1993).

On the other hand, our results do not confirm the inverted U curvilinear relationship between external social capital -directors' links with members of other boards- and the degree of internationalisation of a firm. However, our analysis seems to indicate that this relationship will be negative and significant when we do not include the squared value, which leads us to consider the possibility that the inclusion of directors who increase the number of external links will have negative repercussions on the firm's international performance. This fact is consistent with our negative argument that board members who are "overloaded" by serving on several boards at once cannot devote sufficient time to each one.

We recognise that there are certain limitations to this work. Our study is focused on the boards of large Spanish firms quoted on the Continuous Market. As we have already stated, due to the lack of available databases, we have had to use relevant secondary data in order to construct our own database. We have included these firms in our sample because of their requirement to publish data on their corporate governance and their level of internationalisation. However, these firms are only a part of the total number of Spanish organisations. Secondly, given the specific characteristics of Spanish boards, our results cannot be generalised to other contexts and so the sample should be extended to include other countries, or perhaps a simultaneous or comparative study should be undertaken. Finally, we should continue to research 
our dependent variable, the degree of international diversification, and investigate new sources and methods of measuring the degree of firms' internationalisation. It would also be interesting, since we have this information at our disposal, to study the destination external markets chosen for foreign assets and sales. Not all markets present the same degree of uncertainty, and so in order to achieve the same results, boards need to maintain different levels of human and social capital. It would be useful in future investigations to know the level of internationalisation of the firms that boards are able to access through their interlocks.

A practical implication of this work relates to the selection of board members. In order to increase board effectiveness and to achieve better international results, the selection process should focus on the election of directors who have an existing knowledge and experience of international markets, or who have the required ability to process new information and seek creative solutions in an unstable environment.

To summarise, our investigation contributes to the development of the theory of board effectiveness and how this in turn leads to improved decision-making in the field of internationalisation.

\section{References}

Aguilera, R. and Cuervo-Cazurra, A., 2009, "Codes of Good Governance”. Corporate Governance: An International Review, Vol. 17, Issue 3, pp. 376-387.

Amason, A. C., Shrader, R. C. and Tompson, G. H., 2006, "Newness and novelty: relating top management team composition to new venture performance. Journal of Business Venturing, Vol. 21, Issue 1, pp. 125-148.

Amason, A. and Sapienza, H., 1997, "The effects of top management team size and interaction norms on cognitive and affective conflict". Journal of Management, Vol. 23, Issue 4, pp. 495-516.

Athanassiou, N. and Nigh, D., 1999, “The impact of company internationalization on top management team advice networks: A tacit knowledge perspective". Strategic Management Journal, Vol. 19, Issue 1, pp. 83-92.

Autio, E., Sapienza, H.J. and Almeida, J., 2000, "Effects of age at entry, knowledge intensity, and imitability on international growth". Academy of Management Journal, Vol. 43. Issue 5, pp. 909-924.

Bantel, K.A. and Jackson, S.E., 1989, “Top management and innovations in banking: Does the composition of the top team make a difference?" Strategic Management Journal, Vol. 10 Issue S1, pp. 107-124.

Barney, J.B., 1991, "Firm resources and sustained competitive advantage". Journal of Management, Vol. 17, Issue 1, pp. 99-120.

Barroso, C., Dominguez, M., Vecino, J. and Villegas, M.M., 2009, "Does the team leverage the board's decisions?" Corporate Governance: An International Review, Vol. 17, Issue 6, pp. 744-761. 
Barroso, C., Villegas, M.M. and Pérez-Calero, L., 2011, “Board influence on a firm internationalization”. Corporate Governance: An International Review, Vol. 19, Issue 4, pp. 351-367.

Becker, B.E., Huselid, M.A. and Ulrich, D., 2001, The HR scorecard: Linking people, strategy, and performance. Harvard Business School Press. 235 pp.

Becker, R.A., Chambers, J.M. and Wilks, A.R., 1988, The new S language: A programming environment for data analysis and graphics. Wadsworth \& Brooks/Cole, Pacific Grove, CA. 702 pp.

Calof, J.L., 1993, “The mode choice and change decision process and its impact on international performance”. International Business Review, Vol. 2, Issue 1, pp. 97-120.

Carpenter, M.A. and Fredrickson, J.W., 2001, "Top management teams, global strategic posture, and the moderating role of uncertainty". Academy of Management Journal, Vol. 44, Issue 3, pp. 533-545.

Carpenter, M.A. and Westphal, J.D., 2001, “The strategic context of external networks ties: examining the impact of director appointments on board involvement in strategic decision making”. Academy of Management Journal, Vol. 44, Issue 4, pp. 639-660.

Carter, C.B. and Lorsch, J.W., 2004, Back to the drawing board: Designing corporate boards for a complex world. Harvard Business School Press. 245 pp.

Chen, H-L., 2011, "Does board independence influence the top management team? Evidence from strategic decisions toward internationalization". Corporate Governance: An International Review, Vol. 19, Issue 4, pp. 334-350.

Coleman, J., 1988, "Social capital in the creation of human capital". American Journal of Sociology, Vol. 94, pp. S93-S120.

Conger, J.A., Lawler, E. and Finegold, D.L., 2001, Corporate boards: New strategies for adding value at the top. Jossey-Bass business \& Management series, Wiley. $206 \mathrm{pp}$.

Connelly, B.L., Johnson, J.L., Tihanyi, L. and Ellstrand, A.E., 2011, "More than adopters: Competing influences in the interlocking directorate". Organization Science, Vol. 22, Issue 3, pp. 688-703.

Crabtree, R.G. and Gomolka, E.G., 1991, "Perceptual barriers to consultant utilization: An examination of why manufacturers don't use consultants and what can do about it”. In Bensch, D. and Mugler, J. (eds.), Proceedings of the International Council for Small Business ICSB World Conference, Viena, pp.76-84.

Daily, C., Certo, S. and Dalton, D., 2000, "International experience in the executive suite: The path to prosperity?”. Strategic Management Journal, Vol. 21, Issue 4, pp. 515-523.

Daily, C.M. and Dalton, D.R., 1993, “Board of directors' leadership and structure: control and performance implications". Entrepreneurship Theory and Practice, Vol. 17, Issue 3, pp. 65-81.

Dalton, D. R., Daily, C.M., Johnson, J.L. and Ellstrand, A.E., 1999, "Number of directors and financial performance: a meta-analysis". Academy of Management Journal, Vol. 42, Issue 6, pp. 674-686. 
Dalziel, T., Gentry, R.J. and Bowerman, M., 2011, “An integrated agency-resource dependence view of the influence of directors. Human and relational capital on firms’ R\&D spendingjoms_1003”. Journal of Management Studies, Vol. 48, Issue 6, pp. 1217-1246.

Daniels, J.D. and Bracker, J., 1989, "Profit performance: Do foreign operations make a difference?". Management International Review, Vol. 29, Issue 1, pp.4656.

Datta, D.K., Musteen, M. and Herrmann P., 2009, “Board characteristics, managerial incentives, and the choice between foreign acquisitions and international joint ventures". Journal of Management, Vol. 35, Issue 4, pp. 928-953.

Elango, B. and Sethi, S.P., 2007, "Exploration into the relationship between country of origin (COE) and the internationalization-performance paradigm". Management International Review, Vol. 47, Issue 3, pp. 369-392.

Ellstrand, A.E., Tihanyi, L. and Johnson, J.L., 2002, "Board structure and international political risk". Academy of Management Journal, Vol. 45, Issue 4, pp. 769-777.

Filatotchev I., 2006, “The effects of executive characteristics and venture capital involvement on board composition and share ownership in IPO firms". British Journal of Management, Vol. 17, pp. 75-92.

Filatotchev I., Dynomina N., Wright M. and Buck, T., 2001, "Effects of post privatization governance and strategies on export intensity in the former Soviet Union”. Journal International Business Studies, Vol. 32, Issue 4, pp. 853871.

Finkelstein, S. and Mooney, A.C., 2003, "Not the usual suspects: How to use board process to make boards better". Academy of Management Executive, Vol. 17, Issue 2, pp. 101-113.

Geletkanycz, M.A. and Hambrick, D.C., 1997, “The external ties of top executives" . Administrative Science Quartely, Vol. 42, Issue 4, pp. 654-681.

Geringer, M.J., Beamish, P.W. and daCosta, R.C., 1989, "Diversification strategy and internationalization: Implications for MNE performance”. Strategic Management Journal, Vol. 10, Issue 2, pp. 109-119.

Goll, I., Johnson, N.B. and Rasheed, A.A., 2007, "Knowledge capability, strategic change, and firm performance: The moderating role of the environment" . Management Decision, Vol. 45, Issue 2, pp. 161-179.

Goodstein, J., Gautam, K. and Boeker, W., 1994, "The effects of board size and diversity on strategic change". Strategic Management Journal, Vol. 15, Issue 3, pp. 241-250.

Grant, R.M., 1991, “The resource- based theory of competitive advantage: Implications for strategy formulation”. California Management Review, Vol. 33, Issue 3, pp. 114-135.

Hambrick, D. C. and Mason, P., 1984, "Upper echelons: the organization as a reflection of its top managers". Academy of Management Review, Vol. 9, Issue 2, pp. 193-206. 
Hambrick, D.C., Geletkanycz, M.A. and Fredrickson, J.W., 1993, “Top executive commitment to the status quo: Some tests of its determinants". Strategic Management Journal, Vol. 14, Issue 6, pp. 401-418.

Hausman, J., 1978, "Specification tests in econometrics". Econometrica, Vol. 46, Issue 6, pp. 1251-1272.

Haynes, K.T. and Hillman, A., 2010, “The effect of board capital and CEO power on strategic change”. Strategic Management Journal, Vol. 31, Issue 11, pp. 1145 1163.

Henderson, N., 2005, “Global board dynamics”. Directorship, Vol. 31, Issue 11, pp. 10-21.

Hermalin, B. E. and Weisbach, M.S., 1998, "Endogenously chosen boards of directors and their monitoring of the CEO". American Economic Review, Vol. 88, Issue 1, pp. 96-118.

Hermalin, B.E. and Weisbach, M.S., 2000, Board of directors as an endogenously determined institution: A survey of the literature. Working Paper. University of California at Berkeley and University of Illinois.

Hermalin, B.E. and Weisbach, M.S., 2003, "Boards of directors as an endogenously determined institution: a survey of the economic literature". Economic Policy Review, Vol. 9, Issue 1, pp.7-26.

Hillman, A.J. and Dalziel, T., 2003, "Boards of directors and firm performance: Integrating agency and resource dependence perspectives". Academy of Management Review, Vol. 28, Issue 3, pp. 383-396.

Hillman, A.J., Cannella, A. A. and Paetzold, R., 2000, “The resource dependence role of corporate directors strategic adaptation of board composition in response to environmental change”. Journal of Management Studies, Vol. 37, Issue 2, pp. 235-255.

Hitt, M.A., Tihanyi, L., Miller, T. and Connelly, B., 2006, "International diversification: antecedents, outcomes, and moderators". Journal of Management, Vol. 32, Issue 6, pp. 831-867.

Holm, C. and Schuler, F., 2010, "Reduction of asymmetric information through corporate governance mechanisms - The importance of ownership dispersion and exposure toward the international capital market". Corporate Governance: An International Review, Vol. 18, Issue 1, pp. 32-47.

Jackling, B. and Johl, S., 2009, "Board structure and firm performance: Evidence from India's top companies”. Corporate Governance: An International Review, Vol. 17, Issue 4, pp. 492-509.

Jaw, Y.L. and Lin, W.T., 2009, "Corporate elite characteristics and firm's internationalization: CEO-level and TMT- level roles". The International Journal of Human Resource Management, Vol. 20, Issue 1, pp. 220-233.

Karami, A., Analoui, F. and Kakabadse, N.K., 2006, “The CEOs' characteristics and their strategy development in the UK SME sector: An empirical study". Journal of Management Development, Vol. 25, Issue 4, pp. 316-324. 
Kim Y. and Cannella Jr., A.A., 2008, "Toward a social capital theory of director selection". Corporate Governance: An International Review, Vol. 16, Issue 4, pp. 282-293.

Kim, B., Prescott, J.E. and Kim, S.M., 2005, "Differentiated governance of foreign subsidiaries in transnational corporations: An agency theory perspective". Journal of International Management Vol. 11, Issue 1, pp. 43-66.

Kim, H. and Lin, C., 2010, "Diversity, outside directors and firm valuation: Korean evidence". Journal of Business Research, Vol. 63, Issue 3, pp. 284-291.

Kim, Y., 2005, "Board network characteristics and firm performance in Korea". Corporate Governance: An International Review, Vol. 13, Issue 6, pp. 800-808.

Kim, Y., 2007, "The proportion and social capital of outside directors and their impacts on firm value: evidence from Korea". Corporate governance: An International Review, Vol. 15, Issue 6, PP. 1168-1176.

Kor, Y. and Misanyi, V., 2008, "Outside directors 'industry-specific experience and firm's liability of newness”. Strategic Management Journal, Vol. 29, Issue 12, pp. 1345-1355.

Kor, Y.Y. and Sundaramurthy, C., 2009, "Experience-based human capital and social capital of outside directors". Journal of Management, Vol. 35, Issue 4, pp. 9811006.

Kroll, M., Walters, B. A. and Wright, P., 2008, "Board vigilance, directors experience, and corporate outcomes". Strategic Management Journal, Vol. 29, Issue 4, pp. 363-382.

Lee, H-U. and Park, J-H., 2006, "Top team diversity, internationalization and the mediating effect of international alliances". British Journal of Management, Vol. 17, Issue 3, pp. 195-213.

Lester, R., Hillman A., Zardkoohi, A. and Cannella JR. A.A., 2008, "Former goverment officials as outside directors: the role of human and social capital". Academy of Management Journal, Vol. 51, Issue 5, pp. 999-1013.

Lien, Y.C., Piesse, J., Strange, R. and Filatotchev, I., 2005, "The role of corporate governance in FDI decisions: Evidence from Taiwan". International Business Review, Vol. 14, Issue 6, pp. 739-763.

March, J.G., 1999, The pursuit of organizational intelligence. Blackwell, Malden, M.M and Oxford, U.K.

Mizruchi, M.S., 1996, "What do interlocks do? An analysis, critique and assessment of research on interlocking directorates". Annual Review of Sociology, Vol. 22, Issue 1, pp. 271-298.

Nicholson, G.J. and Kiel, G.C., 2004, "Breakthrough board performance How to harness your board's intellectual capital". Corporate Governance: An International Review, Vol. 4, Issue 1, pp. 5-23.

Ortiz, N. Aragón, J. A., Delgado, J.D. and Ferrón V., 2012, "The effect of director interlocks on firms' adoption of proactive environmental strategies". Corporate Governance: An International Review, Vol. 20, Issue 2, pp. 164-178. 
Pennings, J.M., Lee, K. and van Witteloostujin, A., 1998, "Human capital, social capital, and firm dissolution". Academy of Management Journal, Vol. 41, Issue 4, pp. 425-440.

Petrovic, J., 2008, "Unlocking the role of a board director: a review of the literature”. Management Decision. Vol. 46, Issue 9, pp. 1373-1392.

Petrovic, J., Kakabadse, A. and Kakabadse, N.K., 2006, “International joint venture (IJV) directors' contribution to board effectiveness. Learning from the literature". Management Decision, Vol. 44, Issue 3, pp. 346-366.

Peyrefitte, J., Fadil, P.A. and Thomas, A.S., 2002, “The influence of managerial experiences on large firm internationalization". International Journal of Management, Vol. 19, Issue 3, pp. 495-502.

Pfeffer, J. and Salancik, G., 1978. The external control of organizations: a resource dependence perspective. New York , Harper \& Row. 300 pp.

Pombo, C. and Gutiérrez, L.H., 2011, "Outside directors, board interlocks and firm performance: Empirical evidence from Colombian business groups”. Journal of Economics and Business, Vol. 63, Issue 4, pp. 251-277.

Qian, G., 2002, “Multinationality, product diversification, and profitability of emerging U.S. small- and medium-sized enterprises". Journal of Business Research, Vol. 55, Issue 4, pp. 325-335.

Ramaswamy, K., Kroeck, K.G. and Renforth, W., 1996, "Measuring the degree of internationalization of a firm: A comment". Journal of International Business Studies, Vol. 27, Issue 1, pp. 167-177.

Reeb, D.M. and Zhao, W., 2009. Director Capital and Corporate Disclosure Quality. Working Paper Series, Fox School of Business, Temple University, Philadelphia.

Reuber, A.R. y Fischer, E., 1997, “The influence of the management team's international experience on the internationalization behaviors of SMEs". Journal of International Business Studies, Vol. 28, Issue 4, pp. 807-825.

Rindova, V.P., 1999, "What corporate boards have to do with strategy: a cognitive perspective”. Journal of Management Studies, Vol. 36, Issue 7, pp. 953-975.

Rivas, J.L., 2012, "Co-opting the environment: an empirical test of resource-dependence theory". The International Journal of Human Resource Management, Vol. 23, Issue 2, 294-311.

Rivas, J.L., Hamori, M. and Mayo, M., 2009, "Board composition and firm internationalization”. Academy of Management Proceedings, Vol. 1, pp. 1-6.

Ruigrok, W., Peck, S. and Tacheva, S., 2007, "Nationality and gender diversity on Swiss corporate boards". Corporate Governance: An International Review, Vol. 15, Issue 4, pp. 546-557.

Sambharya, R.B., 1996, "Foreign experiences of top management teams and international diversification strategies of US multinational corporations”. Strategic Management Journal, Vol. 17, Issue 9, pp. 739-746.

Sanders, G. and Carpenter, M. A., 1998, "Internationalization and firm governance: the roles of CEO compensation, top team composition and board structure". Academy of Management Journal, Vol. 41, Issue 2, pp. 158-178. 
Singh, D.A. and Gaur, A.S., 2009, "Business group affiliation, firm governance, and firm performance: Evidence from China and India". Corporate Governance: An International Review, Vol. 17, Issue 4, pp. 411-425.

Singla, C., George, R. and Eliyaht, R., 2010 "Internationalization, family business and corporate governance: an emerging market perspective". Academy of Management Annual Meeting Proceedings, p.1.

Sirmon, D.G., Arregle, J.L., Hitt, M.A., and Webb, J.W., 2008, "The role of family influence in firms' strategic responses to threat of imitation". Entrepreneurship Theory and Practice, Vol. 32, pp. 979-998.

Stevenson, W.B and Radin, R.F., 2009, "Social capital and social influence on the boards of directors”. Journal of Management, Vol. 46, Issue 1, pp. 16-44.

Sullivan, D., 1994, "Measuring the degree of internationalization of a firm". Journal of International Business Studies, Vol. 25, Issue 2, pp. 325-342.

Tallman, S. and Li, J., 1996, "Effects of international diversity and product diversity on the performance of multinational firms". Academy of Management Journal, Vol. 39, Issue 1, pp.179-196.

Thomas, D.E. and Eden, L., 2004, "What is the shape of the, multinationality-performance relationship?”. Multinational Business Review, Vol. 12, Issue 1, pp. 89-110.

Tian, J., Haleblian, J. and Rajagopalan, N., 2011, “ The effects of board human and social capital on investor reactions to new CEO selection". Strategic Management Journal, Vol. 32, Issue 7, pp. 731-747.

Useem, M., 1982, "Classwide rationality in the politics of managers and directors of large corporations in the United States and Great Britain”. Administrative Science Quarterly, Vol. 27, Issue 2, pp. 199-226.

Westphal, J.D. and Zajac, E.J., 1995, "Who shall govern? CEO/Board power, demographic similarity, and new director selection”. Administrative Science Quarterly, Vol. 40, Issue 1, pp. 60-83.

Wiersema, M. and Bantel, K.A., 1992, “Top management team demography and corporate strategic change". Academy of Management Journal, Vol. 35, Issue 1, pp. 91-121.

Wincent, J., Anokhin, S.and Boter, H., 2009, "Network board continuity and effectiveness of open innovation in Swedish strategic small-firm networks". R\&D Management, Vol. 39, Issue 1, pp. 55-67.

Wincent, J., Anokhin, S. and Örtqvist, D., 2010, "Does network board capital matter? A study of innovative performance in strategic SME networks". Journal of Business Research, Vol. 63, Issue 3, pp. 265-275.

Wolff, J.A. and Pett, T.L., 2000, "Internationalization of small firms: An examination of export competitive patterns, firm size, and export performance". Journal of Small Business Management, Vol. 38, Issue 2, pp. 34-47.

Yeung, H.W.-C., 2002, "Entrepreneurship in international business: An institutional perspective". Asia Pacific Journal of Management, Vol. 19, Issue 1, pp. 26-61.

Zahra, S. A., Priem, R. L. and Rasheed, A. A., 2007, "Understanding the causes and effects of top management fraud". Organizational Dynamics, Vol. 36, Issue 2, pp.122-139. 


\section{Notes on Contributors}

Name: Leticia Pérez-Calero Sánchez

Position: Lecturer

School / Faculty: Faculty of Business Sciences

University: University of Pablo de Olavide (Seville)

Address: Ctra. de Utrera Km. 1, Seville 41013

Telephone: +34 954557575

Email: lcalero@upo.es

Name: $M^{a}$ del Mar Villegas Periñán

Position: Associate Professor

School / Faculty: Faculty of Economics and Business Sciences

University: University of Seville

Address: Admon de Empresas y Marketing, Seville 41005

Telephone: +34954556133

Email: marvillegas@us.es

Name: Carmen Barroso Castro

Position: Senior Professor

School / Faculty: Faculty of Economics and Business Sciences

University: University of Seville

Address: Admon de Empresas y Marketing, Seville 41005

Telephone: +34 954557521

Email: barroso@us.es 
